\title{
Profiling ethylene-regulated gene expression in Arabidopsis thaliana by microarray analysis
}

\author{
Guang Yan Zhong · Jacqueline K. Burns
}

(C) Springer Science+Business Media B.V. 2006

Erratum to: Plant Mol Biol (2003) 53(1-2):117-131

DOI: 10.1023/B:PLAN.0000009270.81977.ef

Due to an unfortunate misunderstanding, the first author's name appeared incorrectly in the header of the above mentioned article as:

Guang Van Zhong

where it should have read:

Guang Yan Zhong

The online version of the original article can be found at http://www.dx.doi.org/10.1023/B:PLAN.0000009270.81977.ef

G. Y. Zhong · J. K. Burns $(\bowtie)$

Horticultural Sciences Department, University of Florida, IFAS, Citrus Research and Education Center, 700

Experiment Station Road, Lake Alfred, FL 33850, USA

e-mail: jkbu@lal.ufl.edu 